\title{
LINKS BETWEEN THE MIDDLE TISZA REGION AND THE NORTHERN BALKANS IN THE LIGHT OF OLD AND NEW DATA
}

\author{
Péter F. Kovács ${ }^{1}$
}

\begin{abstract}
In this paper enamel inlayed Celtic brooches from the Middle Tisza Region will be presented and contextualised. Thanks to the intensive metal detecting surveys conducted in recent years, a number of new finds found their way to the museum collections. Until now there are 12 of this type broches are known. 10 are recently discovered and the other two were found at Törökszenmtiklós - Surjány site those are wellrecognized among archaeologists. The amount of new data makes necessary to publish and reconsider the fresh finds and thoughts. In this paper these brooches are presented and analysed. In the light of different finds just as coins, Laminci-type belt buckle we can assume a stronger and more intensive connection between the Middle Tisza Region and the Northern Balkan during the II-I. c. BC.
\end{abstract}

Keywords: Late Iron Age, Middle Tisza Region, North Balkan, Sordisci, Brooches, Laminci type belt buckle

\section{Introduction}

Despite our increasing knowledge on the Late Iron Age of the Middle Tisza Region, there are still several questions yet to be answered. One of these missing links is to understand the nature of contacts between the study area and its closer and distant neighbours. How and to what degree was the Middle Tisza Region integrated into the complex La Tène networks operating in and around the Carpathian Basin? However, at the moment, it is still utterly complicated to approach such questions.

Thanks to the intensive metal detecting surveys conducted in recent years, a number of new finds found their way to the museum collections. Some of these were previously unknown, or only a limited number of specimens have been discovered from the region of focus before. In light of the rising number of artefacts, it might be worth to review our understanding concerning the relations between the Middle Tisza Region and its neighbours, particularly with the Northern Balkan.

\section{History of research - A brief overview}

Until recently, recognition of the Middle Tisza Region's wider relations has been greatly limited. Considering the provenance and type of non-local or foreign-influenced objects, following the transition between the Middle and Late Iron Age several apparent changes can be detected. ${ }^{2}$ During the period of the Vekerzug culture, objects of western origin can also be

\footnotetext{
${ }^{1}$ Damjanich János Museum, Szolnok, Kossuth tér 4, 5000 Hungary. Email: kovacs.peter.uni@gmail.com

${ }^{2}$ F. KOVÁCS 2018A, 95.
} 
found, ${ }^{3}$ typically vessels of the Hallstatt-culture, such as in case of the Törökszentmiklós Surjány cemetery. ${ }^{4}$ The multi-coloured contacts of the period can be clearly illustrated through the wealthy grave of Mezőtúr - Újváros, in which both objects featuring Black Sea characteristics, and a brooch type connected to the Alpine region were unearthed. ${ }^{5}$ It seems that during the period of the La Tène culture those Black Sea contacts disappeared or greatly reduced.

Based on the previous publications, regarding the Alföld region, only the $4^{\text {th }}-3^{\text {rd }}$ century $\mathrm{BC}$ arrival of the western-related groups featuring typically eastern La Tène culture characteristics has been examined, and apart from some peculiar objects - such as the Celtic rython with dragon head from Jászberény - Cserőhalom cemetery ${ }^{6}$ or the pseodu-kernos pottery vessel from Tiszafüred - Morotvapart site - specific details of cross-regional relations have less been recognized. Moreover, as the above finds are unique artworks, their exact provenance is quite problematic to define, thus mostly art-influences can be detected. Non-local (raw) materials can also provide a better understanding on the outer connections of Middle Tisza region, such as the sapropelite and graphite, as those materials arrived to the region from the area of modern-day Czech Republic. ${ }^{8}$

The above general assumptions might be qualified by the re-consideration of numismatic evidence, according to which some of the coins discovered in the Middle Tisza region were possibly minted at the Syrmia region of the Northern Balkan, ${ }^{9}$ while others were minted at the area of modern-day Slovakia ${ }^{10}$ and Romania. ${ }^{11}$ Examination of glass bracelets also showed that those mostly (but not exclusively) arrived from Northern/North-western Slovakia, ${ }^{12}$ although a single piece withefive-ribs showing characteristics of the western regions was also discovered. ${ }^{13}$ The iron sword with an anthropomorphic stamp from the vicinity of Jászjákóhalma, a stray find, might have also been made in a western workshop. ${ }^{14}$

\section{Enamel Brooches - A link towards the Northern Balkan}

From the $3^{\text {rd }}$ century BC onward, decorating various objects with enamel technique is relatively common amongst Celtic groups (besides brooches, belt plaques, horse harnesses, knobs and other costume ornaments can also be found), however present paper will only focus on the enamel inlayed brooches discovered in Jász-Nagykun-Szolnok County. Altogether 12 specimens have been discovered to date, out of which only two were known from publications before. The new unpublished objects all reached the collections of the Damjanich János Museum and the Jász Museum through metal detecting surveys. ${ }^{15}$ Although those items are all surface findings, it is important to emphasise that exact GPS coordinates are available verifying their locations.

${ }^{3}$ F. KOVÁCS 2018A, 92

${ }^{4}$ CSALOG/KISFALUDI 1985.

5 KISFALUDI 1983.

${ }^{6}$ SZABÓ 2005, 150-151.

7 KRIVECZKY 1991; SZABÓ 2005, 172.

${ }^{8}$ F. KOVÁCS 2016; F. KOVÁCS 2018A, 94-95.

9 F. KOVÁCS 2018A, 94; TORBÁGYI/F. KOVÁCS 2019, 42-43; TORBÁGYI in press

${ }^{10}$ F. KOVÁCS 2018A, 94; TORBÁGYI/F. KOVÁCS 2019, 42-43; TORBÁGYI in press

${ }^{11}$ F. KOVÁCS 2018A, 94; TORBÁGYI/F. KOVÁCS 2019, 42-43; TORBÁGYI in press

${ }_{12} \mathrm{~F}$. KOVÁCS in press.

${ }^{13}$ F. KOVÁCS in press

14 TORBÁGYI/F. KOVÁCS 2020, 3. tábla 3.

${ }^{15}$ I would like to express my sincere gratitude to András Gulyás who kindly gave me the permission to publish the finds from the collection of Jász Múzeum. 
These objects might provide new insights towards the understanding of the crossregional relations of the Middle Tisza Region.

The first in-depth research on Celtic enamel inlay brooches from the Carpathian Basin was conducted by I. Sellye ${ }^{16}$ who dated them to the Late LT period and saw them as parts of chain-belts. ${ }^{17}$ I. Hunyady also dated them to the late LT-Roman imperial period, and suggested that those might developed in the 'Southern regions' ${ }^{18}$ Following the increasing number of reports ${ }^{19}$ a new theory was formulated suggesting that the enamel brooch type developed during the transitional period Middle LT - Late LT, and was used during the Late LT. ${ }^{20}$ According to M. Guštin those brooches served as essential parts of the Scordisci female attire. ${ }^{21}$ P. Popović considered that the so-called Zemun type brooches were made by local artisans of the Eastern Syrmia region, and arrived to the Dacian-Getic areas via the 'Little Scordisci'. ${ }^{22}$ P. Popović dates the type between the $2^{\text {nd }}-1^{\text {st }}$ century BC. ${ }^{23} \mathrm{M}$. Guštin defines two main groups of enamel brooches, namely the type with square-shaped plaques of the Middle LT and the triangular type of the Late LT, which has specimens with triangular plaques. His distribution map suggests that both types are concentrated on the Sava region, and he sees their spread as result of migration. ${ }^{24}$ M. Dizdar differentiates seven groups of enamel inlay brooches based on the decorations of their plaques, ${ }^{25}$ and suggests that during the Middle LT period several workshops situated on the eastern Celtic territories might have existed. ${ }^{26}$ In case of the brooches from the vicinity of Zenum, he sees the theory suggesting that those were made in local Syrmian workshops being well-grounded. ${ }^{27}$ On the next few pages Dizdar's classification will be followed.

In the territory of Hungary only a few enamel inlay brooches have been known to date: from Törökszentmiklós - Surjány, ${ }^{28}$ from Szeged - Kiskundorozsma, ${ }^{29}$ from Balatonboglár Berekre-dülö, ${ }^{30}$ and also an uncertain and unpublished piece from Dunaújváros. ${ }^{31}$ Recently two enamel brooches were discovered in Sajópetri - Homoki-szőlőskert cemetery. ${ }^{32}$ One (no. 28/90) has a square-shaped plaque decorated with a dot-circle pattern, ${ }^{33}$ the other (no. 57/127) features a square-shaped plaque with pattern of five triangular impressions. ${ }^{34}$

Previously only one site yielding enamel brooches was known from the Middle Tisza Region, namely the completely destroyed Törökszentmiklós - Surjány cemetery, from which a pair of brooches had been discovered (Pl. II/1). The condition of the two objects is remarkably good; they were published by I. Stanczik and A. Vaday in the journal entitled Folia

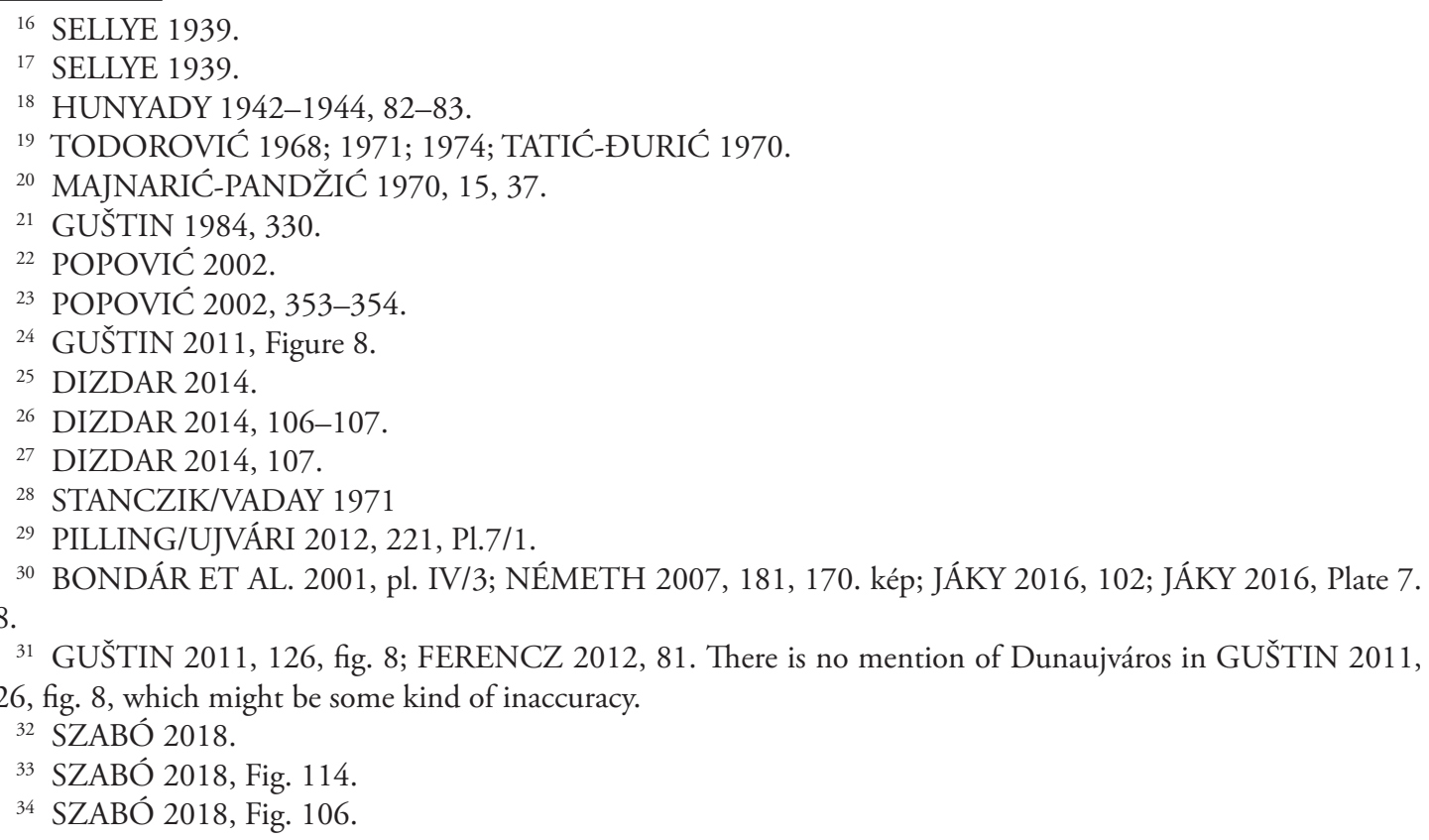


Archaeologica. ${ }^{35}$ Although the items can be considered as exceptionally high-quality examples of enamel brooches, it is important to take into account that these brooches are stray findings without any stratigraphical or archaeological context, being brought to the museum along with other objects. Whereas I. Stanczik and A. Vaday mention in one of their footnotes that the brooches and the well-recognized zoomorphic belt-hook were discovered in the same grave, ${ }^{36}$ in fact no properly excavated Celtic graves are known from the vicinity of Törökszentmiklós Surjány. Meanwhile, it is a reasonable assumption to theorize a rich and significant cemetery in the area, which was completely destroyed by the intensive sand-mining. ${ }^{37}$ It is also a well-known fact that during the '50s and " 60 s a number of objects from the Törökszentmiklós area arrived to the museum collection by means of purchase, thus their archaeological context is unknown. Out of the dozen artefacts from Törökszentmiklós - Surjány, there is none from secure context or with any written documentation. In this manner, although the above brooches are often cited by various publications ${ }^{38}$, and are generally considered as grave goods, ${ }^{39}$ without knowing their context or other accompanying finds, such hypothesis must be taken with certain caution. Their possible connection to the zoomorphic belt-hook is also questionable, as there is no relevant data available to indicate that these objects were found in the same grave. Thus, any chronological assumptions based on the hypothesised relationship of these finds should also be reconsidered.

From a typological perspective, the Törökszentmiklós brooches seem to be analogous to another enamel brooch from an unknown location, ${ }^{40}$ thus based on the similarities, M. Dizdar suggests that the unknown piece might also have been derived from the Tisza region. ${ }^{41}$

A similar object was discovered in Szeged - Kiskundorozsma site, from settlement context, possibly from a constructed dwelling as the brooch was found in its upper layer. ${ }^{42}$ The filling of the square-shaped plaque is very similar both to the Törökszentmiklós pieces and to the one published by Sellye, as the centre motifs are bordered by four smaller patterns positioned in the corners. At the same time the centre motif itself differs slightly: in case of Kiskundurozsma it resembles to a rhomboid while in case of Törökszentmiklós it is more like a 'star'.

Two new finds are analogous to this 'Törökszentmiklós-type'. A fragment discovered via metal detecting survey in Törökszentmiklós - Szenttamás (Pl. I/9, Pl. III/9), which also has a 'star'-shaped central motif along with curved patterns in the corners. It is filled with red enamel inlay, but the whole object is very fragmented, even its plaque is broken, although the knob is still visible and the object can be easily identified. Another fragment was found in Túrkeve - Vecserke part, also via metal detecting survey(Pl. I/10, Pl. III/10), which is identical to the pieces from Törökszentmiklós - Szenttamás and Törökszentmiklós - Surjány, and to the item published by Sellye. A slightly similar composition is visible on the specimen from GospođinciSuma Parohija site, but the form of the central and corner-patterns are different, ${ }^{43}$ thus it cannot be seen as a close analogy. From Besenyszög - Nagy-Fokorú 3. site a fragment of enamel inlayed brooch was found (Pl. I/1, Pl. III/1). Unfortunately this piece is only a small fragment but it's

35 STANCZYK/VADAY 1971.

36 STANCZYK/VADAY 1971, 23, footnote 82.

37 Other published objects from the theorized cemetery: F. KOVÁCS 2017, 42-43; KOVÁCS 1982, 146. Several entries of weapons, costume ornaments and various potteries can be found in the old acquisition registers of the local collection of Törökszentmiklós, however detailed descriptions of those would exceed the limits of this paper.

38 STANCZIK/VADAY 1971, 24, fig. 3/4-5; SZABÓ 1988, fig. 51; TELEAGĂ 2008, 95, fig.5/2.

39 DIZDAR 2014, 103.

40 SELLYE 1939, pl. II/9.

41 DIZDAR 2014, 103.

42 PILLING/UJVÁRI 2012, 221, pl.7/1

43 MEDOVIĆ 1998, 92, pl. 46/4; POPOVIĆ 2002, 353, pl. II/10; DIZDAR 2014, 102-103. 
probably similar to the other 'Törökszentmiklós-type' broches. It was found together with a piece of bronze belt (Pl. II/2).

Another fragment is known from Kunhegyes - Jajjhalom (Pl. I/5, Pl. III/5), again thanks to metal detecting survey. Its flared head is anchor-like just above the spring, and its square-shaped plaque is situated between two knobs. On its reverse side it is clearly visible that the reverse parts areattached to the bow by one of the knobs. The square-shaped plaque features sand-dial shaped patterns, the middle is in horizontal, the two on the sides are in vertical position. Exactly the same composition is yet unknown in the literature, as most often a circle is positioned between the two sand-dials, such as in case of Zenum - Kapela, ${ }^{44}$ Căpuşu Mare, ${ }^{45}$ Alba Iulia, ${ }^{46}$ and Obišovce. ${ }^{47}$ Another brooch with sand-dial decoration was discovered from settlement context (house no. 153) at Balatonboglár - Berekre-dülő site, ${ }^{48}$ but in this case the horizontally positioned pattern completely fills the plaque.

Two other fragments were discovered at Tiszajenő - Boc-ér site no. 2. (Pl. I/6-7, $\mathrm{Pl}$. III/6-7), again via metal detecting survey. One of these also fits into the above typological series (Pl. I/7, Pl. III/7). The square-shaped plaque is bordered by two smaller knobs, it possibly has an anchor-like head, which has been broken. The plaque is decorated with a circle-shaped impression positioned between two vertical sand-dial motifs. Similar objects are known from Zenum - Kapela, ${ }^{49}$ Căpuşu Mare, ${ }^{50}$ Alba Iulia, ${ }^{51}$ and Obišovce ${ }^{52}$ sites. The plaque of the other fragment from Tiszajenő - Boc-ér site no. 2 (Pl. I/6, Pl. III/6) is decorated with a composition of three pairs of (possibly) interlocking triangles, and there are four dot-circle motifs between the triangles. This type can be considered as an example of the so-called Boljevci variant, and the distributionof this variant is concentratingon the main territory of the Scordisci. ${ }^{53}$

Pieces featuring a square-shaped plaque positioned between two knobs and decorated with a simple impression following the shape of the plaque are particularly interesting. In these cases, the head becomes anchor-like towards its end. From the Middle Tisza Region, altogether three examples have been discovered to date, all via metal detecting surveys: Tiszapüspöki Fehértó-part felett (Pl. I/8, Pl. III/8), and Jászjákóhalma - Négyszállásitó (2 pieces) (Pl. I. 3-4, $\mathrm{Pl}$. III/3-4). These specimens are all relatively small in size and comparatively 'crowded': the width of the plaques and knobs is approximately the same, and the knobs are very close to the plaques. A number of fragments of such brooches are known from the Zenum area, as well as an intact piece. ${ }^{54}$ Another example is known from the Kamenjača cemetery, Sarajevo area, which was interestingly used as a kind of pendant and was unearthed from a female burial along with LT B2 Duchcov-type brooches. ${ }^{55}$ The chronology of this variant has not yet been clarified as sev-

${ }_{44}$ TODOROVIĆ 1968, 153, pl. LIII/12; TODOROVIĆ 1971, 152, pl. LXVIII/7; POPOVIĆ 2002, 352, pl. II/8, DIZDAR 2014, Pl. 1/11.

${ }_{45}$ RUSTOIU 1997 ,

${ }^{46}$ MOGA 1981, 81, fig. 2; BELDIMAN 1993, 181, fig. 2/1; RUSTOIU 1997, fig. 25/13; DIZDAR 2014, Pl. $2 / 1$.

47 PIETA 2010,

${ }^{48}$ BONDÁR ET AL. 2001, pl. IV/3; NÉMETH 2007, 181, fig. 170; JÁKY 2016, 102; JÁKY 2016, pl. 7/18.

49 TODOROVIĆ 1968, 153, pl. LIII/12; TODOROVIĆ 1971, 152, pl. LXVIII/7; POPOVIĆ 2002, 352, pl. II/8, DIZDAR 2014, Pl. 1/11.

${ }^{50}$ RUSTOIU 1997.

${ }^{51}$ MOGA 1981, 81, fig. 2; BELDIMAN 1993, 181, fig. 2/1; RUSTOIU 1997, fig. 25/13; DIZDAR 2014, Pl. 2/1.

52 PIETA 2010.

53 POPOVIC 2002; DIZDAR 2014, Fig. 5.

54 TODOROVIĆ 1971, 153, pl. LXIX/9; POPOVIĆ 2002, 353, pl. III/6; DIZDAR 2014, 99.

55 PAŠKVALIN 1975, 60, pl. XXXII/9; PAŠKVALIN 2002, 335, pl.4/4; PAŠKVALIN 2008, 121, pl. 13/10; DIZDAR 2014, 100. 
eral pieces are lacking proper context. J. Todorović and P. Popović dates these brooches to the $1^{\text {st }}$ century BC. ${ }^{56}$ There is also a specimen from Ilişua site which was dated to $2^{\text {nd }}-1^{\text {st }}$ century BC. ${ }^{57}$ Based on their distribution, it seems that their production area might have been the territory of Syrmia, or possibly the Scordisci sphere of influence.

The fragment from the vicinity Jászjákóhalma - Szászegyház seems to belong to the above group as the plaque is decorated with a similar composition (Pl. I/2, Pl. III/2), but the size of the plaque is double, while the size of the filling is half of the other known examples from Tiszapüspöki - Fehértó-part felett, and Jászjákóhalma - Négyszállásitó (2 pieces.). Thus, the Jászjákóhalma - Szászegyház piece has a more elegant, almost graceful appearance, which suggests that it might be a hybrid variant.

As M. Dizdar suggests, brooches with different decoration might indicate different workshops. ${ }^{58}$ This theory might be supported by the fact that there are more brooches with a 'star'-shaped central decoration from the area of Törökszentmiklós. At the same time, altogether less than half a dozen of such objects have been discovered in the Middle Tisza Region to date, thus it would be rather unfounded to visualize a local workshop. M. Guštin connects the distribution of enamel brooches to the migration of the Taurisci and Scordisci of the Sava area, ${ }^{59}$ which seems to be a plausible explanation in case of the pieces from the Middle Tisza Region as well. Meanwhile, the possibility of exchange and trade between the two regions cannot be ruled out, nor the existence of a fragile cultural-political sphere of influence of the Scordisci incorporating the Middle Tisza Region during the second half of the $3^{\text {rd }}$ century $\mathrm{BC}$ - end of $2^{\text {nd }}$ century $\mathrm{BC} /$ beginning of $1^{\text {st }}$ century BC.

Dating enamel brooches is quite problematic from several aspects. Number of stray finds is greatly over-represented, there are some from settlement context and only a few from datable graves. In some cases, enamel brooches were found together with brooches of LT B2 dates, but there is piece from Ardeu - Cetăţuie site from settlement context dated to the $1^{\text {st }}$ century $\mathrm{BC},{ }^{60}$ more precisely, it is very likely that the brooch is dated to the second half of the $1^{\text {st }}$ century BC, to the period when the fortificationhad been built. ${ }^{61}$ At the same time, it is important to take into account that the Ardeu - Cetăţuie specimen has no enamel decoration, thus it could fit into more than one category formed by Dizdar. ${ }^{62}$ At any rate, the chronological inconsistencies of enamel brooches cannot be dissolved until discovering more finds from stratigraphical context.

\section{Another possible Scordisci Link? The Laminci- type belt plaque from Törökszentmiklós area}

In 1971 an enormous belt plaque with Illyr-Celtic characteristics was discovered from the area of Törökszentmiklós-Surjány(Pl. II/3), unfortunately without context. ${ }^{63}$ The object was mentioned by T. Kovács who compared it to another belt plaque from Nyergesújfalu, which was discovered during dredging. ${ }^{64}$ These so-called Laminci-type belt plaques can be found in the

56 TODOROVIĆ 1968, 153-155, pl. LIII/10-11, 13-15; LV/14-15; TODOROVIĆ 1971, 150-153, pl. LXVIII/9, 12, 14; LXIX/1, 3, 5; POPOVIĆ 2002, 352-353, pl. III/4-5, 7-9.

57 RUSTOIU 1997, 99; GAIU 2000, 192, fig. 6/4.

58 DIZDAR 2014, 106-107.

59 GUŠTIN 2011, 125.

${ }^{60}$ FERENCZ 2012, 79-80, fig. 1.

61 BODÓ/FERENCZ 2004, 153.

${ }^{62}$ DIZDAR 2014.

63 According to A. Vaday the object was discovered in an inhumation burial during earthworks, but unfortunately the grave and its furnishings have been completely destroyed except the belt plaque. A. Vaday, personal communication.

64 KOVÁCS 1982. 
Illyro-Celtic culture province, and were part of the female costume. ${ }^{65}$ Recently, the topic of belt plaques has been revised by M. Guštin, who defined the Nyergesújfalu and Törökszentmiklós pieces as an individual group, called Nyergesújfalu-group. ${ }^{66}$ Decoration of the Nyergesújfalu and Törökszentmiklós items is quite unique, but the Laminci-group can be considered as their closest analogy ${ }^{67}$ thus it is possible that the style might have been derived from that type. Belt plaques with Illyro-Celtic and Thracian-Dacian ${ }^{68}$ characteristics can be dated to the Late LT period, but individual pieces might have been used until the $1^{\text {st }}$ century BC. ${ }^{69}$ T. Kovács dates the Nyergesújfalu item to the $1^{\text {st }}$ century $\mathrm{BC},{ }^{70}$ thus the Törökszentmiklós piece most likely has the same date.

Exact origin of the variant is yet unknown, but it seems that its closest analogies can be found among the Laminci A group, such as Novo mesto - Beletovvrt, Karaburma, gr. 14. The Laminci A belt plaques are concentrated in the Scordisci territory, and might have been made on the lower course of the Sava. ${ }^{71}$ Along these lines, it is possible that the Nyergesújfalu variant might also have developed on some degree of Scordisci transfer or influence.

\section{Numismatic evidence}

Thanks to the intensive metal detecting surveys, several coins arrived to the DamjanichJános and Jász museums in the last couple of years. ${ }^{72} \mathrm{M}$. Torbágyi's works showed that in some cases the mints might be localised to the Syrmia region, the Northern Balkan or the Lower Duna area, ${ }^{73}$ such as the coins from Kengyel - Baghymajor-Bügeoldal, ${ }^{74}$ Újszász Védgátsor $3{ }^{75}$ or Szajol - Tinókaér. ${ }^{76}$ At the moment, only ten Celtic coins are known from Jász - Nagykun - Szolnok County, thus further conclusions cannot be derived. At the same time, it is already visible that the coins of Balkanic origin form a relatively distinct group.

\section{Other possible links: the settlements}

Settlements discovered in the Middle Tisza Region might also provide further evidences towards possible links with the Northern Balkan. Only a very limited number of settlements dated to the $2^{\text {nd }}-1^{\text {st }}$ century BC have been discovered up to present, although J. Cseh unearthed and published a site, namely Szelevény - Sweiger-tanya where a building of a supposedly $2^{\text {nd }}-1^{\text {st }}$ century BC date had been discovered. Finds from the settlement typically show an articulation of Middle LT and Late LT pottery forms. Among these shreds the author connected a few fragments - interestingly - to the Scordisci pottery making tradition. ${ }^{77}$ However, it is important to take into account that similar potteries were discovered at Karcsa; those were connected to the Przeworsk culture by K. Tankó, who suggested a possible cultural component arriving from the territories of Southern Poland. ${ }^{78}$

\footnotetext{
${ }^{65}$ DRNIĆ 2009, 317.

66 GUŠTIN 2011, 247.

67 GUŠTIN 2011, 247.

68 GUŠTIN 2011, 240.

69 DRNIĆ 2009, 318

70 KOVÁCS 1982, 155-156.

71 GUŠTIN 2011, 251.

72 F. KOVÁCS 2018A; TORBÁGYI/F. KOVÁCS 2019; TORBÁGYI/F. KOVÁCS 2020; TORBÁGYI in press.

73 TORBÁGYI/F. KOVÁCS 2019; TORBÁGYI/F. KOVÁCS 2020; TORBÁGYI in press.

74 TORBÁGYI/F. KOVÁCS 2019, 42.

75 TORBÁGYI/F. KOVÁCS 2019, 43.

76 TORBÁGYI in press.

77 CSEH 2003, 12, fig. 4, 5; CSEH 2003, 53.

78 TANKÓ 2018, 98-100.
} 
A more certain and well-recognized example is Tiszafüred-Morotvapart site, where a Celtic settlement was unearthed through rescue excavation conducted by the Damjanich János Museum in $1984 .{ }^{79}$ On the floor of the house no. 9, from a red, burnt layer, fragments of a socalled pseudo-kernos were discovered. ${ }^{80}$ The object can be dated to the $2^{\text {nd }}-1^{\text {st }}$ century $\mathrm{BC}$, and based on its analogy from Novo Mesto, it might have been derived from the Northern Balkanic cultural sphere. ${ }^{81}$

\section{Conclusion}

For a long period of time only a vague outline on cross-regional connections of the Late Iron Age Middle Tisza Region could be formed, and our understanding was merely based on broader regional tendencies. Nonetheless, the several new finds discovered in recent years give a fresh insight through which it is now possible to visualize a more peculiar image of the study area. Thanks to the recently found enamel brooches and numismatic evidence along with the re-evaluation of earlier discoveries (such as the enamel brooches and belt plaque from Törökszentmiklós, the case of Szelevény - Sweigertanya, or the pseudo-kernos from Tiszafüred), existence of a complex intertwined network operating between the Middle Tisza Region and the Northern Balkan-llyro-Celtic cultural sphere is taking shape, which might have reached its peak during the $2^{\text {nd }}-1^{\text {st }}$ centuries BC. It is possible that during the mid-LT and Late LT a narrow volume of a trade network was operating along the Tisza and Zagyva valleys, which might have connected the Northern and Southern regions of the Carpathian Basin via a North-South axis, incorporating the Middle Tisza Region. The above introduced objects might have been moved along this 'route', although certain items from the Northern territories could also reach the study area, such the Érsekújvár-type bracelets. ${ }^{82}$

At any rate, a deeper understanding on the relations between the two regions would require a greater number of data from secure context.

\section{List of objects}

Besenyszög - Nagy-Fokorú 3. (Pl. I/1, Pl. III/1)

Acquisition number: 2020.11.1.

Description: fragment of a square-shaped plaque bronze brooch. The plaque is decorated with red enamel inlay. There is a semi-pierced whole filled with red enamel on the knob.

Dimensions: Length of the plaque: $0,5 \mathrm{~cm}$, width: $1,6 \mathrm{~cm}$, total length: $1 \mathrm{~cm}$

References: unpublished

Jászjákóhalma-Szászegyház (Pl. I/2, Pl. III/2)

Acquisition number: 2020.15.1.1. (Jász Museum)

Description: Square-shaped plaque of a bronze brooch. A square-shaped impression is visible on the plaque with traces of red enamel inlay. Fragment of the foot being attached to plaque from the direction of the knob also remained.

Dimensions: Length of the plaque: $1 \mathrm{~cm}$, width: $1,7 \mathrm{~cm}$, total length: $2 \mathrm{~cm}$

References: unpublished

Jászjákóhalma - Négyszállásitó (Pl. I/3, Pl. III/3)

Acquisition number: 2020.15.2.1.

\footnotetext{
${ }^{79}$ LASZLOVSZKY/KRIVECZKY/CSEH 1985; KRIVECZKY 1991.

${ }^{80}$ LASZLOVSZKY/KRIVECZKY/CSEH 1985, 4-8; KRIVECZKY 1991, 72.

81 SZABÓ 2005, 172.

82 See: F. KOVÁCS in press.
} 
Description: fragment of a bronze brooch. A square-shaped plaque with square-shaped impression is positioned between a bigger and a smaller knob. No traces of enamel inlay are visible. On its back its visible that a small bronze wire joins to the bigger knob, which might be used to fasten the back plaque to the foot.

Dimensions: Length of the plaque: $0,5 \mathrm{~cm}$, width: $1 \mathrm{~cm}$, total length: $2 \mathrm{~cm}$

References: unpublished

Jászjákóhalma - Négyszállásitó (Pl. I/4, Pl. III/4)

Acquisition number: 2020.15.2.2.

Description: fragment of a bronze brooch.A square-shaped plaque on the back with traces of red enamel inlay. A knob is visible in the direction of the spring, which fastens the back to the wire. The head is anchor-like, although it is partly broken

Dimensions: Length of the plaque: $0,8 \mathrm{~cm}$, width: $1,2 \mathrm{~cm}$, total length: $2,6 \mathrm{~cm}$

References: unpublished

Kunhegyes-Jajjhalom (Pl. I/5, Pl. III/5)

Acquisition number: 2020.11.2.

Description: Square-shaped plaque of a bronze brooch. The plaque has three sand-dial-shaped impressions filled with traces of red enamel. The middle sand-dial is smaller compared to the two on the sides. The plaque is positioned between two knobs, the one closer to the spring was used to fasten the plaque to the back, remains of wire are still visible in it. The head is anchor-like but broken.

Dimensions: Length of the plaque: $1,2 \mathrm{~cm}$, width: $2 \mathrm{~cm}$, total length: $2,8 \mathrm{~cm}$

References: unpublished

Tiszajenő - Bocér 2. (Pl. I/6, Pl. III/6)

Acquisition number: 2020.11.4.

Description: square-shaped plaque of a bronze brooch. The plaque is decorated with a composition of three pairs of (possibly) interlocking triangles, and there are four dot-circle motifs between the triangles. The triangles are filled with green or yellow enamel. The plaque is connected to a knob, this knob was used to fasten the plaque to the back, remains of wire are still visible in it. The head is anchor-like.

Dimensions: Length of the plaque: $1,5 \mathrm{~cm}$, width: $2 \mathrm{~cm}$, total length: $3 \mathrm{~cm}$

References: unpublished

Tiszajenö-Bocér 2. (Pl. I/7, Pl. III/7)

Acquisition number: 2020.11.3.

Description: square-shaped plaque of a bronze brooch. The plaque has a small rounded impression between two sand-dial-shaped impressions filled with traces of red enamel. The plaque is positioned between two knobs, the one closer to the spring was used to fasten the plaque to the back, remains of wire are still visible in it. The head is anchor-like but broken.

Dimensions: Length of the plaque: $1,2 \mathrm{~cm}$, width: $2 \mathrm{~cm}$, total length: $2,8 \mathrm{~cm}$

References: unpublished

Tiszapüspöki-Fehértó-part felett (Pl. I/8, Pl. III/8)

Acquisition number: 2020.11.5.

Description: fragment of a bronze brooch. A square-shaped plaque with traces of red enamel inlay is situated on the back. A knob is visible in the direction of the spring, which fastens the back to the wire. The head is anchor-like, although it is partly broken. A smaller knob is positioned in the direction of the foot, a small groove for the wire is also visible on its back.

Dimensions: Length of the plaque: $0,6 \mathrm{~cm}$, width: $1,2 \mathrm{~cm}$, total length: $2,6 \mathrm{~cm}$

References: unpublished

Törökszentmiklós - Surjány (Pl. II/1)

Acquisition number: 63.291.7.(1-2) 
Description:bronze brooches with rectangular plate between two buttons on the back, decorated with a red enamel inlay. The central depressionfilled withenamel is forms a "star", while a semicircle can be observed in the corners of the square. The brooches have long feet that, above the low trapezoidal bow and between small knobs. The foot widens in the form of an anchor above the spring that was composed of six coils with external cord The needle holder and the reclining leg are made of the same bronze wire, to which a square plate on the back was attached, which was fixed with the two buttons. The plaque and anchor-shaped head and the two buttons is a structural element that is subsequently attached to the fibula.

Dimensions:width of the plaque: $2,2 \mathrm{~cm}$, total length: 7,3

References: STANCZIK/VADAI 1971; F. KOVÁCS 2017, 43.

Törökszentmiklós - Szenttamás (Pl. I/9, Pl. III/9)

Acquisition number: 2020.11.6.

Description: fragment of a bronze brooch. A square-shaped plaque with a composition of a star-shaped middle impression accompanied by four curved motifs in the corners is situated on the back. All have traces of red enamel inlay. One single knob is attached to the fragment, possible in the direction of the foot.

Dimensions: Length of the plaque: $1,6 \mathrm{~cm}$, width: $2 \mathrm{~cm}$, total length: $2,9 \mathrm{~cm}$

References: unpublished

Türkeve - Vecserke-part (Pl. I/10, Pl. III/10)

Acquisition number: 2020.11.7.

Description: fragment of a bronze brooch. A square-shaped plaque with a composition of a star-shaped middle impression accompanied by four curved motifs in the corners is situated on the back. All have traces of red enamel inlay. One single knob is attached to the fragment from the direction of the foot. Dimensions: Length of the plaque: $1,5 \mathrm{~cm}$, width: $2,4 \mathrm{~cm}$, total length: $4,6 \mathrm{~cm}$

References: F. KOVÁCS 2018B

\section{BIBLIOGRAPHY}

BODÓ/FERENCZ 2004

C. BODÓ/I. V. FERENCZ, Câteva consideraţii privind fortiicaţia și așezarea dacică de la Ardeu (com. Balșa), jud. Hunedoara. Istros 11, 2004, 147-158.

BELDIMAN 1993

C. BELDIMAN, Fibule de schemă Latène C cu placă emailată din România. Apulum XXVIIXXX, 1990-1993, 181-188.

BONDÁR ET AL. 2000

M. BONDÁR/SZ. HONTI/V. KISS, A tervezett M7-es autópálya Somogy megyei szakaszának megelőző régészeti feltárása (1992-1999). Előzetes jelentés I. (Kaposvár 2000), 93-114.

\section{CSALOG/KISFALUDI 1985}

ZS. CSALOG/J. KISFALUDI, Skythenzeitliches Gräberfeld in Törökszentmiklós-SurjánÚjtelep. ActaArchHung XXXVII, 3-4, 1985, 307-344.

\section{CSEH 2003}

J. CSEH, Kelta ház Szelevény mellett.Tisicum - A Jász-Nagykun-Szolnok Megyei Múzeumok Évkönyve 13 (Szolnok 2003), 49-67.

\section{DIZDAR 2014}

M. DIZDAR, Bronze Fibulae with Enamel Inlay from Scordiscan Sites. In: S. BERECKI 
(ed.), Iron Age Crafts and Craftsmen in the Carpathian Basin. Proceedings of the International

Colloquium from TârguMureş 10-13 October2013, BMM VII (Cluj-Napoca 2014), 97-114.

DRNIĆ 2009

I. DRNIĆ, Dvije Pojasne Kopče Tipa Laminci Iz Dalja. VjesAMusZagreb XLII, 2009, 305-319.

FERENCZ 2012

I. V. Ferencz, Late Iron Age Brooch with Enamelled Plaque from Ardeu. Marisia XXXII, 2012, 79-84.

\section{F. KOVÁCS 2016}

P. F. KOVÁCS, La Téne-kori „szapropleit” karikaékszerek Jász-Nagykun-Szolnok megyéből. La Tène 'Sapropelite' Armrings from Jász-Nagykun-Szolnok County. Tisicum - A Jász-NagykunSzolnok Megyei Múzeumok Évkönyve 25 (Szolnok 2016), 193-206.

\section{F. KOVÁCS 2017}

P. F. KOVÁCS, Szkíták és kelták öröksége. A vaskor régészete Jász-Nagykun-Szolnok megyében. Legacy of Schithians and Celts. Archaeology of the Iron Age in Jász-Nagykun-Szolnok County. Szolnoki Régészeti Tanulmányok 1. Archaeological Papers of Szolnok 1 (Szolnok 2017).

\section{F. KOVÁCS 2018a}

P. F. KOVÁCS, Traces of Local Interactions and Regional Connections in the Middle Tisza Region. In: S. BERECKI/A. RUSTOIU/M. EGRI (eds.), Iron Age Connectivity in the Carpathian Basin Proceedings of the International Colloquium From TârguMureş 13-15 October2017 (Cluj-Napoca 2018), 91-97.

\section{F. KOVÁCS 2018b}

P. F. KOVÁCS, La Tène-kori településrészletek a Közép-Tisza-vidékről: TiszapüspökiHolt-Tisza-part, Túrkeve-Burkus halom, Szolnok-Vegyiművek körzet. La Tène Age Settlement Sections from the Middle Tisza Region Tiszapüspöki - Holt-Tisza part, Túrkeve - Burkushalom, Szolnok - Vegyimüvekkörzet (Szolnok-Chemical factory district). Tisicum - A Jász-NagykunSzolnok Megyei Múzeumok Évkönyve 26 (Szolnok 2018), 93-114.

\section{F. KOVÁCS IN PRESS}

P. F. KOVÁCS Kelta üvegkarperecek a Közép - Tisza-vidéken. Celtic Glass Bracelets from the Middle Tisza region (East Hungary). Tisicum - A Jász-Nagykun-Szolnok Megyei Múzeumok Évkönyve 29 (Szolnok). Inpress.

\section{GAIU 2000}

C. GAIU, Découvertes Latène à Ilişua, département de Bistriţa-Năsăud. In: C. GAIU/A. RUSTOIU (eds.), Les Celtes et les Thraco-Daces de l'est du bassin des Carpates. Les actes du colloque national qui a eu lieu a Bistriţa le 16-17 octobre 1998, BMB Seria Historica 3 (Cluj-Napoca 2000), 189-200.

\section{GUŠTIN 1984}

M. GUŠTIN, Die Kelten in Jugoslawien. JbRGZM 31, 1984, 305-363.

\section{GUŠTIN 2011}

M. GUŠTIN, On the Celtic tribe of Taurisci. Local identity and regional contacts in the ancient world. In: M. GUŠTIN/M. JEVTIĆ (eds.), The Eastern Celts, The Communities between the Alps and the Black Sea (Koper - Beograd 2011), 119-130. 


\section{GUŠTIN 2011}

M. GUŠTIN, Eastern Imports from the end of Late Iron Age at Novo mesto / Slovenia. In: D. MĂGUREANU/D. MĂNDESCU/S. MATEI (eds.), Archaeology: Making of and Practice. Studies in Honor of Mircea Babeş at his 70th anniversary (Piteşti 2011), 239-254.

HUNYADY 1942-1944

I. HUNYADY, Kelták a Kárpát-medencében, Szövegkötet. DissPan II.18 (Budapest 1942-1944).

KISFALUDI 1983

J. KISFALUDI, Szkítakori sír Mezőtúrról. AÉrt 110, 1983, 69-73.

KOVÁCS 1982

T. KOVÁCS, Latènezeitliches Gürtelblech Südlicher Herkunft in Ungarn. Savaria 16, 1982, 145-159.

\section{KRIVECZKY 1991}

B. KRIVECZKY, A késő vaskori (kelta) telep. Régészeti ásatások Tiszafüred-Morotvaparton. In:

L. TÁLAS/L. MADARAS (eds.) Szolnok Megyei Múzeumi Adattár 32 (Szolnok 1991), 65-96.

\section{LASZLOVSZKY/KRIVECZKY/CSEH 1985}

J. LASZLOVSZKY/B. KRIVECZKY/J. CSEH, Településnyomok és temetkezések az őskortól a későközépkorig a tiszafüredi Morotvaparton. Múzeumi Levelek 47-48 (Szolnok 1985), 3-27.

MAJNARIĆ-PANDŽIĆ 1970

N. MAJNARIĆ-PANDŽIĆ, Keltsko-latenska kultura u Slavoniji i Srijemu (Vinkovci 1970).

MEDOVIĆ 1998

P. MEDOVIĆ, Die Geländebegehungenim Raum um das Titeler Plateau 1965 und 1969. In: B. HÄNSEL/P. MEDOVIĆ (eds.), Feudvar I, Das Plateu von Titel und die Šajkaška (Kiel 1998), 41-140.

MOGA 1981

V. MOGA, Notiţe archeologice apulense. Apulum XIX, 1981, 79-82.

NÉMETH 2007

P. G. NÉMETH, Kelta zománcdíszes és korall berakásos fibulák. In: K. BELÉNYESY/SZ. HONTI/V. KISS (eds.), Gördülő idő. Régészeti feltárások az M7-es autópálya Somogy megyei szakaszán Zamárdi és Ordacsehi között (Budapest 2007), 181-182.

\section{PAŠKVALIN 1975}

V. PAŠKVALIN, “Kamenjača”, Ul. 6. april, Breza kod Sarajeva - mlađe željezno dobska i rimska desitijatska nekropola. APregl 17, 1975, 57-62.

PAŠKVALIN 2002

V. PAŠKVALIN, Inhumirani grobžene na Kamenjači u Brezi nekropoli pre drimskih Dezitijata, Godišnjak-Sarajevo 30, 2002, 329-348.

PAŠKVALIN 2008

V. PAŠKVALIN, Kamenjača, Breza kod Sarajeva - mlađe željezno dobna i rimska nekropola, Godišnjak- Sarajevo XXXVII/35, 2008, 101-179. 
PIETA 2010

K. PIETA, Die keltische Besiedlung der Slowakei, Jüngere Latènezeit. Archaeologica Slovaca Monographiae Studia XII (Nitra 2010).

\section{PILLING/UJVÁRI 2012}

ZS. PILLING/F. UJVÁRI, Iron Age Settlement and Cemetery from Szeged-Kiskundorozsma. In: S. BERECKI (ed.), Iron Age Rites and Rituals in the Carpathian Basin. Proceedings of the International Colloquium from Târgu Mureş, 7-9 October 2011 (Târgu Mureş 2012), 217-248.

POPOVIĆ 2002

P. POPOVIĆ, Enamel and Scordisci. Godišnjak-Sarajevo 30, 2002, 349-361.

RUSTOIU 1997

A. RUSTOIU, Fibulele din Dacia Preromană (sec. II î.e.n. - I e.n.) (București 1997).

SELLYE 1939

I. SELLYE, Császárkori emailmunkák Pannoniából. DissPann II. 8 (Budapest 1939).

STANCZIK/VADAY 1971

I. STANCZIK/A. VADAY, Keltische Bronzegürtel "ungarischen” Typus im Karpatbecken. FolA XXII, 1971, 7-27.

SZABÓ 1988

M. SZABÓ, Les Celtes en Pannonie. Contribution à l'histoire de la civilisation celtique dans la cuvette des Karpates (Paris 1988).

SZABÓ 2005

M. SZABÓ, A keleti kelták. A késő vaskor a Kárpát-medencében (Budapest 2005).

TATIĆ-ĐURIĆ 1970

M. TATIĆ-ĐURIĆ, Zbirka fibula i aplikacija sa emajlom. ZborMuzBeograd XIV, 1970, 81-92.

TELEAGĂ 2008

E. TELEAGĂ, Die La-Tène-zeitliche Nekropole von Curtuişeni/Érkörtvélyes (Bihor, Rumänien). Der Forschungsstand. Dacia N. S. LII, 2008, 85-165.

TODOROVIĆ 1968

J. TODOROVIĆ, Kelti u jugoistočnoj Evropi. Dissertationes et Monographiae VII (Beograd 1968).

TODOROVIĆ 1971

J. TODOROVIĆ, Katalog praistorijskih metalnih predmeta. Katalog III, Muzej grada Beograda (Beograd 1971).

TODOROVIĆ 1974

J. TODOROVIĆ, Skordisci. Monumenta Archaeologica 2 (Novi Sad-Beograd 1974).

\section{TORBÁGYI/F. KOVÁCS 2019}

M. TORBÁGYI/P. F. KOVÁCS, Celtic coins from the Middle Tisza Region (Jász-NagykunSzolnok County, East Hungary). Acta Numismatica Hungarica I, 2019, 42-44. 


\section{TORBÁGYI/F. KOVÁCS 2020}

M. TORBÁGYI/P. F. KOVÁCS, Kelta érmek és egyéb La Tène-kori leletek Jászjákóhalma környékéről. Celtic Coins and Othe rLa Tène Age Finds from the Vicinity of Jászjákóhalma. Tisicum - A Jász-Nagykun-Szolnok Megyei Múzeumok Évkönyve 28 (Szolnok 2020), 43-56.

\section{TORBÁGYI IN PRESS}

M. TORBÁGYI, Kelta érmek az Alföldön. New Celtic Coins from the Great Hungarian Plain. In: P. F. KOVÁCS PÉTER/A. KELEMEN/J. TÁRNOKI (eds.) Évezredek a Közép-Tisza mentén. Kapcsolatok és hálózatok (régészeti tanulmányok a Közép-Tisza-Vidék múltjáról) Szolnoki Régészeti Tanulmányok 2. Archaeological Papers of Szolnok 2. 


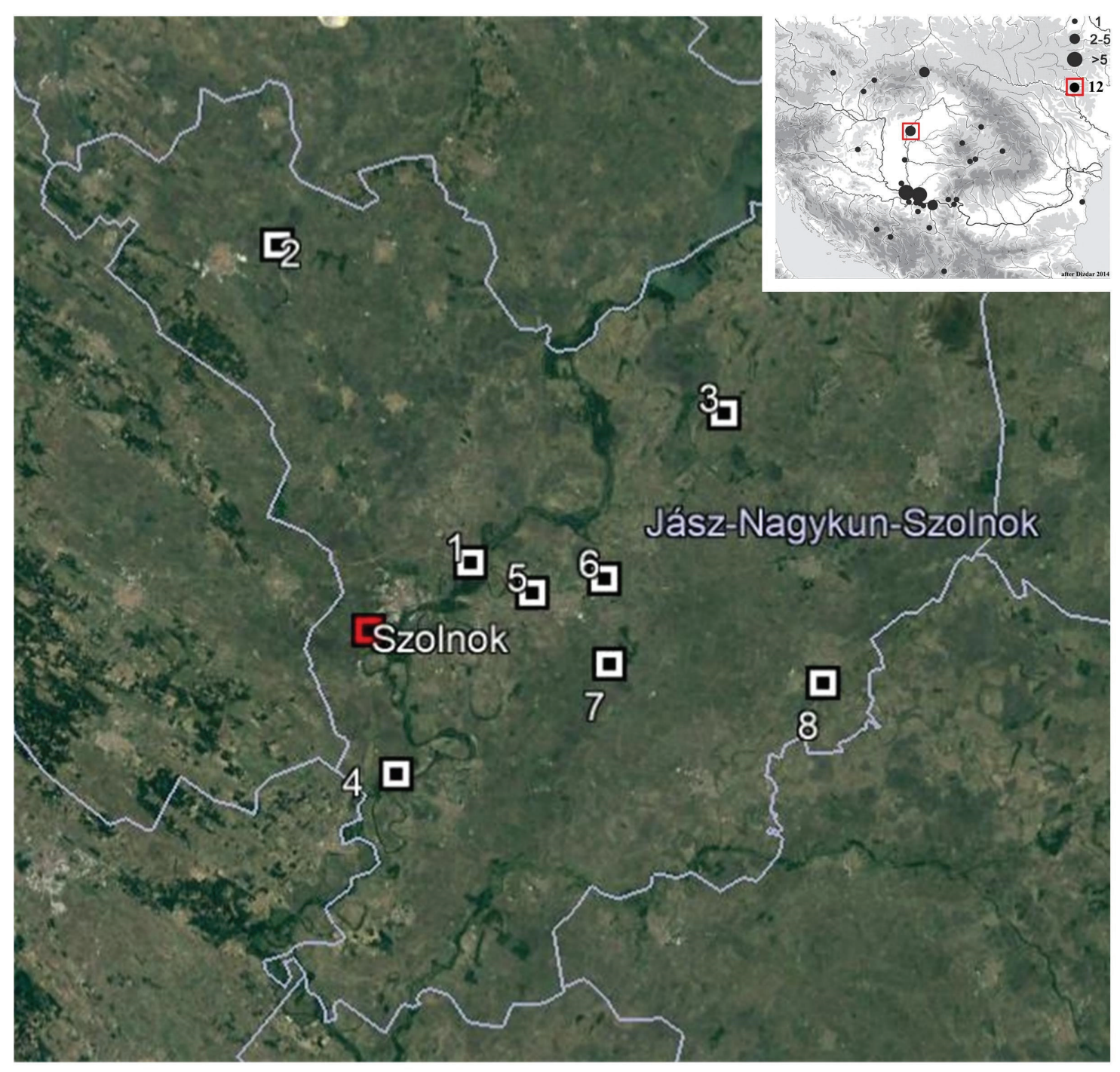

Fig. 1. Distribution map of enamel inlayed brooches in the Middle Tisza Region. 


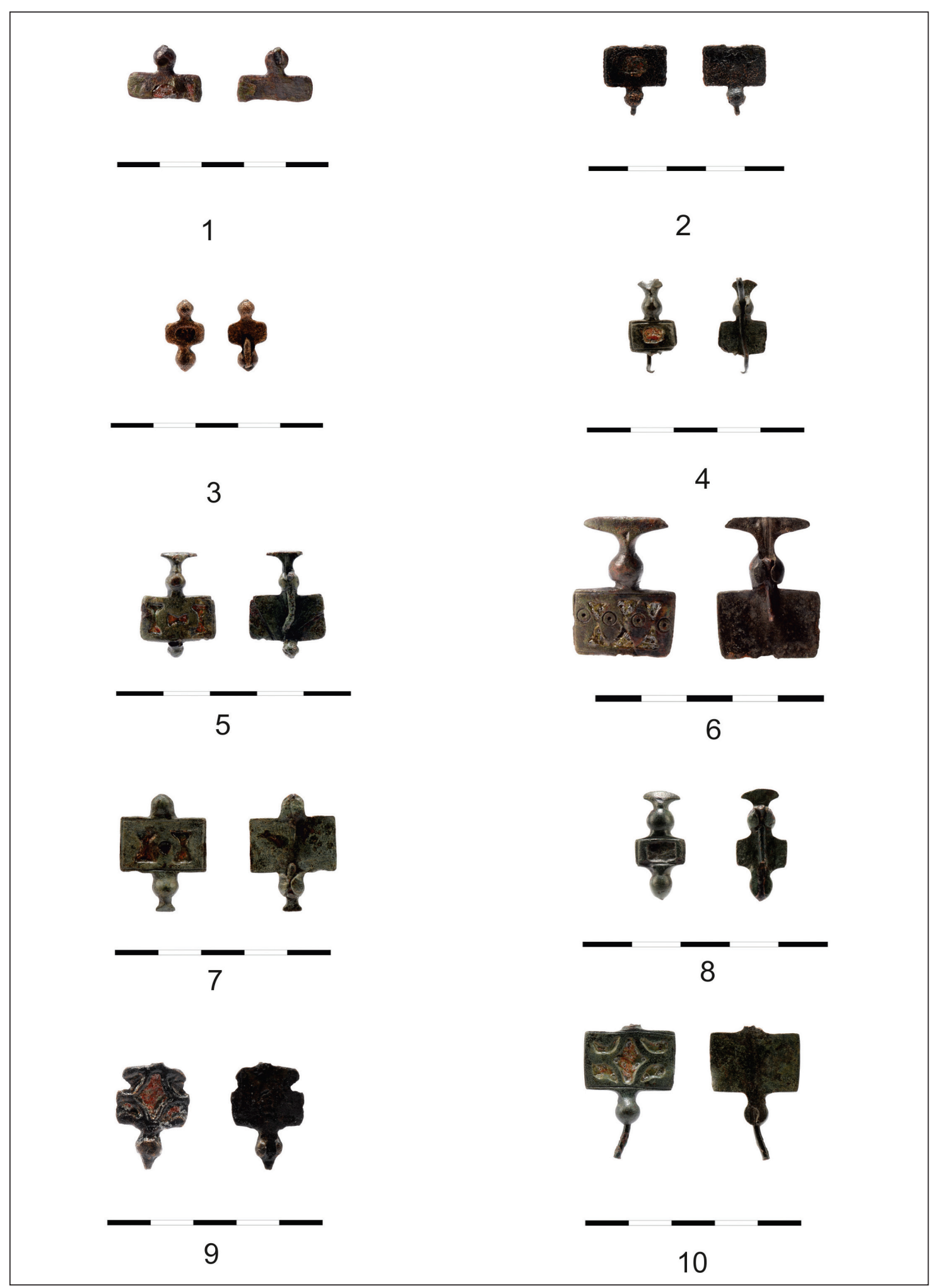

Pl. I. Enamel inlayed brooches from the Middle Tisza Region: 1. Besenyszög - Nagy Fokorú 3; 2. Jászjákóhalma - Szászegyház; 3-4. Jászjákóhalma - Négyszállásitó; 5. Kunhegyes - Jajjhalom; 6-7. Tiszajenő - Bocér 2; 8. Tiszapüspöki -Fehértó-part felett; 9. Törökszentmiklós - Szenttamás; 10. Túrkeve - Vecserke-part. 


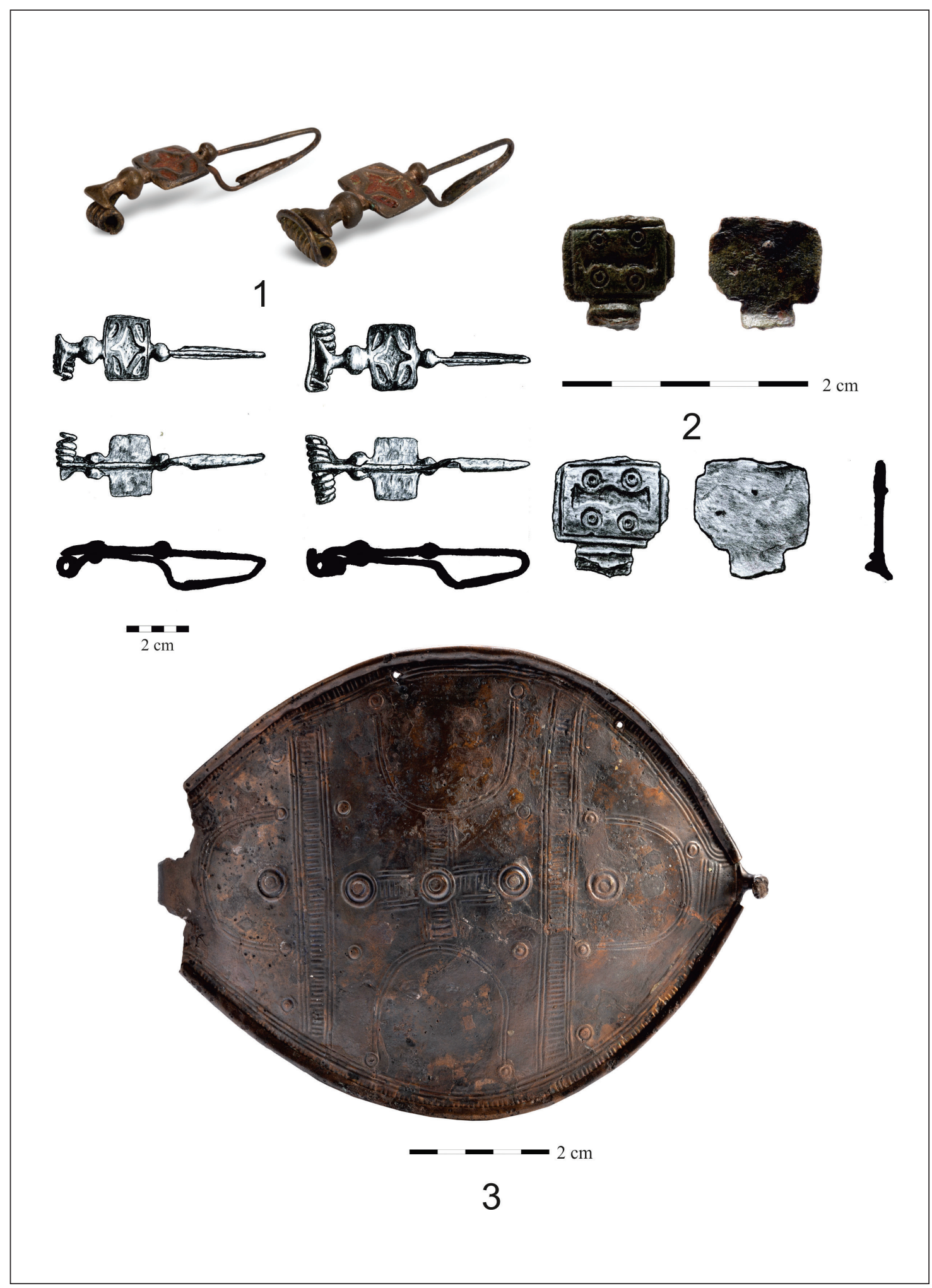

Pl. II. 1. Brooches from Törökszentmiklós - Surjány; 2. Fragment of bronze belt from Besenyszög - Nagy Fokorú 3; 3. Bronze belt buckle from Törökszentmiklós. 

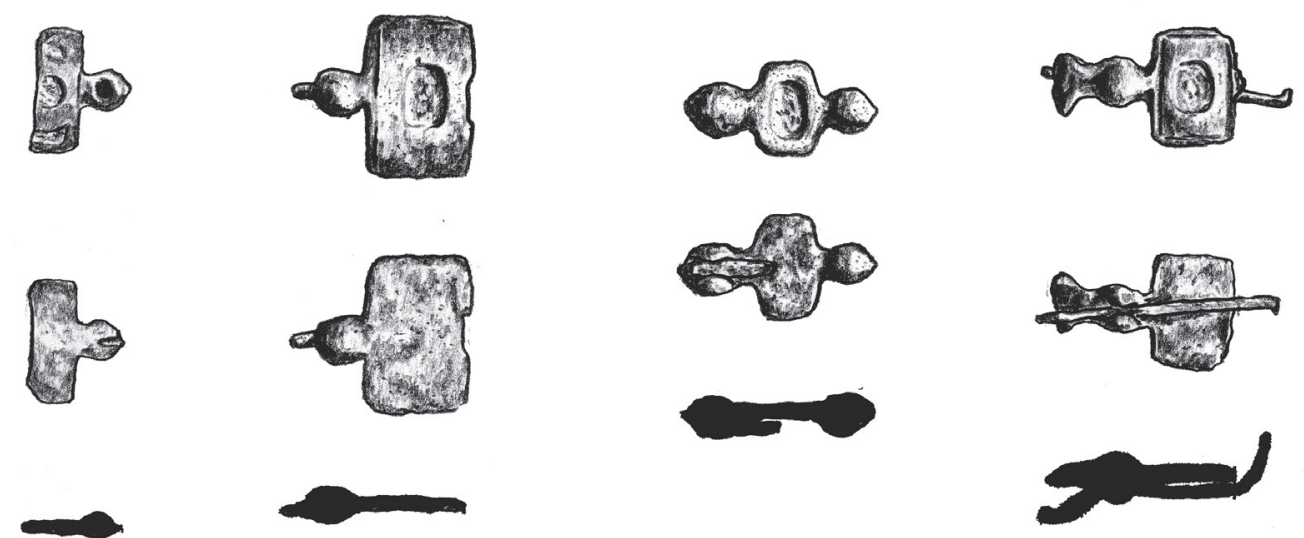

3
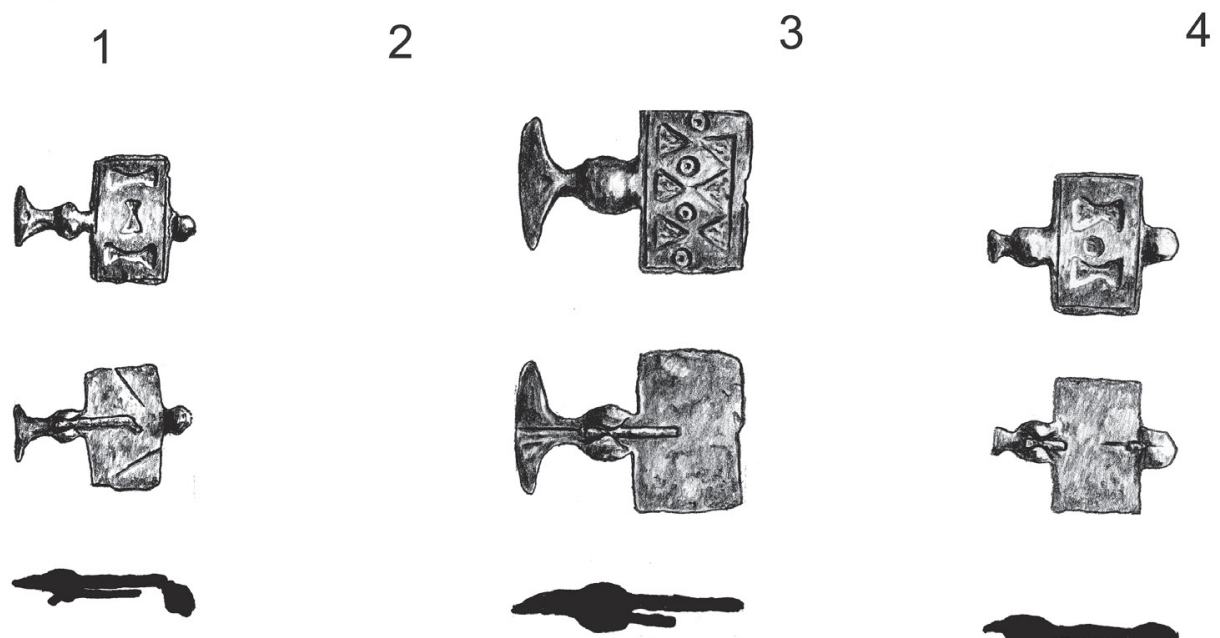

6

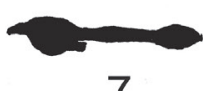

5
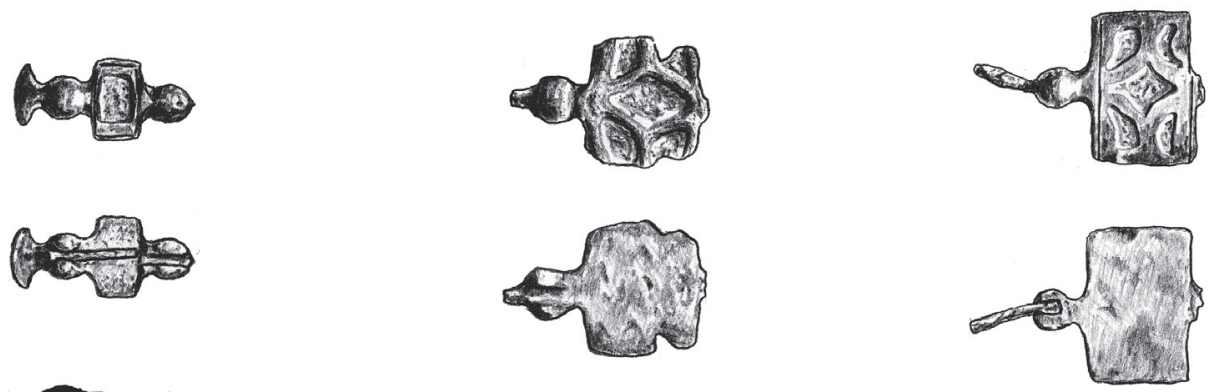

8
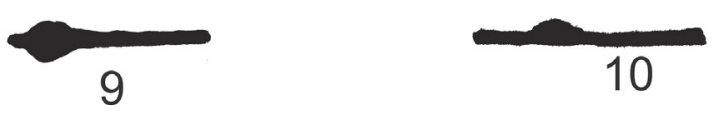

Plate III. Enamel inlayed brooches from the Middle Tisza Region: 1. Besenyszög - Nagy Fokorú 3; 2. Jászjákóhalma - Szászegyház; 3-4. Jászjákóhalma - Négyszállásitó; 5. Kunhegyes - Jajjhalom; 6-7. Tiszajenő Bocér 2; 8. Tiszapüspöki -Fehértó-part felett; 9. Törökszentmiklós - Szenttamás; 10. Túrkeve - Vecserke-part. 